\title{
Effect of active antimicrobial films on the growth of pathogenic bacteria in Mantı
}

\author{
Sinan UZUNLU1*
}

\begin{abstract}
The current study assessed antimicrobial films for use in active food packaging. Mant1, a tortellini-like Turkish food, was packaged with antimicrobial films to extend refrigerated storage time at $4{ }^{\circ} \mathrm{C}$. Polycaprolactone (PCL) was separately incorporated with cinnamaldehyde (CNMA) and pomegranate methanolic extract (PME) to form antimicrobial diffusion films for use against two common food-poisoning bacteria, Escherichia coli and Staphylococcus aureus, and the mantı pieces were separately inoculated with $5 \log$ concentrations of both types of bacteria. The films and mant 1 were then inserted in polyethylene bags, which were filled with $100 \% \mathrm{~N}_{2}$ gas and monitored at $4{ }^{\circ} \mathrm{C}$ for 28 days. The results clearly show that both a low temperature storage $\left(4^{\circ} \mathrm{C}\right)$ and antimicrobial films controlled microbial growth in packages of mant kept in a modified atmosphere $\left(100 \% \mathrm{~N}_{2}\right)$ for a 28 -day period. The findings are promising from an industrial standpoint with regard to bakery foods that are packaged and preserved for short-term periods (<30 days).
\end{abstract}

Keywords: active packaging; pomegranate; cinnamaldehyde; mant1; antibacterial.

Practical Application: To test the feasibility of using compounds of cinnamon and pomegranate in the vapour phase of food packaging.

\section{Introduction}

Foodborne illnesses caused by pathogenic microorganisms result in economic losses and are a major concern of food industry and regulatory agencies throughout the world. The Centers for Disease Control and Prevention recently reported that in 2016, 24,029 infections, 5,512 hospitalizations, and 98 deaths were caused by nine foodborne pathogens. Campylobacter, Salmonella, Shigella, Shiga toxin-producing Escherichia coli, Cryptosporidium, Yersinia, Vibrio, Listeria, and Cyclospora resulted in descending numbers of confirmed infections in the US in that year (Marder et al., 2017).

Preventing spoilage and foodborne illnesses is now accomplished with active antimicrobial packaging (Hafsa et al., 2016; Wen et al., 2016). Active packaging mainly refers to controlled-release packaging, which is a new generation of food packaging. Bioactive compounds are released from the packaging materials into the packed food in a controlled manner. The rate of the release from the film to the packed food should be optimised (Yam \& Zhu, 2012).

Traditional foods that must be transported to distant locations should be resistant to spoilage. One such food, mant1, requires an active packaging system to become transportable. Mant1, a tortellini-like food, consists of a wheat dough ( $75 \% \mathrm{w} / \mathrm{w}$ of mant 1 ) filled with minced beef, onion, and spices $(25 \% \mathrm{w} / \mathrm{w}$ of mant1). The packaging is typically applied using a vacuum or a modified atmosphere (Sitti, 2011). Vacuum and modified atmosphere packaging help extend the shelf life of mant1. This mant 1 is a highly perishable product due to its high water activity $(>0.87)$, moisture $(>40 \%)$, and $\mathrm{pH}$ content (6.0-7.0), as well as its nutrients, which are beneficial for microorganism growth (Uzunlu \& Var, 2016). Previous researches has focused on modified-atmosphere packaging that employs high levels (40-80\%) of carbon dioxide (Yücetepe, 2011; Uzunlu \& Var, 2016).

Therefore, the current study aimed to provide an antimicrobial polycaprolactone film in a modified-atmosphere $\left(100 \% \mathrm{~N}_{2}\right)$ package for mantı storage at $4{ }^{\circ} \mathrm{C}$ that could protect against artificially inoculated bacteria. Natural bio-active compounds are released from bio-degradable polymers, such as polycaprolactone, in a controlled manner. Polycaprolactone is a miscible polymer of polyethylene and polyvinylchloride, and it controls the release rate of bio-active compounds effectively (Boumail et al., 2013; Martínez-Abad et al., 2013; Uzunlu \& Niranjan, 2017). Escherichia coli and Staphylococcus aureus are the most common food-pathogenic bacteria and indicators of the hygienic conditions of production, and these bacteria are investigated in the current study. Because pomegranate and cinnamon are widely studied fruits that contain compounds that are bio-active against the growth of foodborne pathogens, their relative levels of bio-activity are examined in this study (Duman et al., 2009; Nanasombat \& Wimuttigosol, 2011; Sanla-Ead et al., 2012).

\section{Materials and methods}

\subsection{Materials}

Polycaprolactone (density $1.1 \mathrm{~g} / \mathrm{mL}$, average molecular weight $14,000 \mathrm{~g} / \mathrm{mol}$ in flake form), CNMA with a purity of $\geq 95 \%$, chloroform ( $\geq 99 \%$ ), methanol ( $\geq 99.8 \%$ ), sodium carboxymethylcellulose (CMC, average molecular weight $250,000 \mathrm{~g} / \mathrm{mol}$ ), peptone 
water $(0.1 \%)$, tryptic soy broth and tryptic soy agar (TSA) were purchased from Sigma-Aldrich (United Kingdom). Fresh Punica granatum fruits (178.58 g, country of origin: Peru), beef mince (fat content $<20 \%$, collagen/meat protein ratio $<25 \%$ ), and wheat flour were purchased from a local market in Reading, Berkshire (United Kingdom).

\subsection{Pomegranate plant extraction}

Arils from the pomegranate fruits were oven-dried (Memmert, Germany) at $40^{\circ} \mathrm{C}$ for $48 \mathrm{~h}$. The dried material (38.01\% moisture content) was then weighed in Whatman cellulose extraction thimbles and placed inside a Soxhlet extractor apparatus for exhaustive extraction via methanol (99.8\%). This procedure created a claret-red diluted solution. The methanol was then removed using a rotary evaporator (Büchi, Switzerland), yielding $29.28 \mathrm{~g}$ of methanolic extract ( $16 \%$ of the entire fruit), and stored at $4{ }^{\circ} \mathrm{C}$ until further use.

\subsection{Preparation of antimicrobial PCL films}

Polycaprolactone films ( $8.5 \mathrm{~cm}$ diameter) with $1 \mathrm{wt} \%$ CNMA and $10 \mathrm{wt} \%$ PME (in terms of the dry weight of the PCL) were prepared via solvent casting, a modification of the method developed by Martínez-Abad et al. (2013). In brief, 1 g PCL, $1 \mathrm{~g}$ CMC (used as a stabiliser), $0.01 \mathrm{~g}$ CNMA, and $0.1 \mathrm{~g}$ PME were dissolved in $20 \mathrm{~g}$ chloroform at ambient temperature while stirring with a magnetic stir bar until the PCL was dissolved. The solutions were then cast onto glass lenses ( $85 \mathrm{~mm}$ in diameter) and allowed to dry at ambient temperature $\left(\sim 23^{\circ} \mathrm{C}, \sim 55 \%\right.$ relative humidity) for $24 \mathrm{~h}$ before peeling. The appearance of the films was clear and did not affect the odour of the mant in the PE bags $(30 \times 20 \mathrm{~cm})$.

\subsection{Transmission and ATR- FTIR analysis}

The attenuated total reflectance Fourier transform infrared (ATR-FTIR) spectra of all film samples were recorded using a Perkin Elmer Spectrum 100 FT-IR Spectrometer (USA). The analysis was performed within the spectral region of $530-4000 \mathrm{~cm}^{-1}$, with eight scans recorded at a resolution of $0.5 \mathrm{~cm}^{-1}$. The spectra were analysed using Spectrum 10.03.06 software.

\subsection{Mantı preparation}

A total of $670 \mathrm{~g}$ mant 1 were prepared from $450 \mathrm{~g}$ wheat flour, $100 \mathrm{~g}$ beef mince, and $150 \mathrm{~mL}$ sterilised distilled water. The dough was prepared by mixing the wheat flour and water. High hydrostatic pressure was applied (600 MPa for 15 minutes at $22^{\circ} \mathrm{C}$ ) to inactivate the indigenous microbial flora of both the beef mince and dough prior to the inoculation of the mant 1 with the bacterial cultures. Stansted Fluid Power Ltd (UK) high pressure instrument was used at the food process centre, University of Reading Food and Nutritional Sciences Department (UK). The dough was then sheeted by cutting it into equal squares with an average sheet thickness of $0.41 \mathrm{~mm}$ using a kitchen knife. Each square of dough (1.125 $\pm 0.1 \mathrm{~g})$ was filled with $0.375 \pm 0.1 \mathrm{~g}$ of high pressurised beef mince, and the squares were then folded diagonally by hand to form the distinctive shapes needed. The pieces of mantı were then gently heated in an oven for 4 minutes until they reached a core temperature of $60{ }^{\circ} \mathrm{C}$. The temperature was continuously monitored via two copper-constant thermocouples inserted into the core of each mantı piece. The mantı pieces were then left at an ambient temperature $\left(20^{\circ} \mathrm{C}\right)$ for approximately 30 minutes prior to their inoculation with bacterial cultures.

\subsection{Inoculation of mantı with bacterial cultures and study design}

Escherichia coli K12 NCTC 10538 and Staphylococcus aureus NCTC 01803 strains were acquired from the National Collection of Type Cultures (NCTC, United Kingdom). Each culture was propagated in tryptic soy broth and incubated at $37^{\circ} \mathrm{C}$ for $24 \mathrm{~h}$. Cells were then centrifuged at 5,000 g for 10 minutes at $4^{\circ} \mathrm{C}$ and washed twice in peptone water. The supernatant was discarded, and the pellets were diluted before inoculation into the mant1 packages to obtain a final concentration of 5 logs CFU/mL by incubating at $37^{\circ} \mathrm{C}$ for $24 \mathrm{~h}$ using TSA plates.

Thirty six packages of mantı were prepared. The mant packages composed of 15 grams of mant samples (the weight of one piece is $1.5 \pm 0.1 \mathrm{~g}$ ). The mant 1 packages (contains 10 mant pieces) were then divided into three groups (twelve packages were used for each group) as follows: Group I was a control group, Group II was the PCL-PME film group, and Group III was the PCL-CNMA film group. $500 \mu \mathrm{L}$ of bacterial cultures of E. coli or $S$. aureus were separately inoculated with either mant1 packages ( $50 \mu \mathrm{L}$ per each mantı pieces) for each group. Bacterial cultures were pipetted into the distinctive shapes of each mant 1 pieces. The packages of Group II and Group III were inserted either with their respective antimicrobial films into PE bags, while Group I were not inserted with antimicrobial films as well as a neat PCL film. These packages were filled with $100 \% \mathrm{~N}_{2}$ gas and sealed using a Multivac A 300 packaging unit (under 2 bars pressure and $75 \mathrm{~L} / \mathrm{min}$ gas flow) prior to cold storage at $4{ }^{\circ} \mathrm{C}$ for 28 days ( $34 \%$ relative humidity).

\subsection{Antimicrobial activity of PCL films in mantı packages and monitoring of microbial growth}

The three groups of mant packages, the control group (Group I), PCL-PME film group (Group II), and PCL-CNMA film group (Group III), were monitored to evaluate the antimicrobial activity of the bioactive compounds against E. coli and $S$. aureus. All samples were monitored on Days 1, 4, 7, 14, 21, and 28 of the refrigerated storage period. A total of $10 \mathrm{~g}$ of mant 1 samples were weighed in sterile stomacher bags containing $90 \mathrm{~mL}$ peptone water $(0.1 \%)$ and homogenised in a stomacher (Seward 400, UK) at $230 \mathrm{rpm}$ for 2 minutes. Serial decimal dilutions were prepared and spread onto TSA. Plates were incubated at $37^{\circ} \mathrm{C}$ for $24-48 \mathrm{~h}$ prior to counting the colonies.

\subsection{Scanning Electron Microscopy (SEM)}

An FEI quanta FEG 600 environmental scanning electron microscope with an acceleration voltage of $20 \mathrm{kV}$ was used. The surfaces of the films were sputtered with gold before analysis. 


\subsection{Film thickness measurement}

Measurements were obtained using a digital micrometer (Kkmoon, China) in $0.01 \mathrm{~mm}$ resolution.

\section{$2.10 a_{w}$ measurement}

After mild heat treatment at $60^{\circ} \mathrm{C}$ for 4 minutes, the $\mathrm{a}_{\mathrm{w}}$ of the mant 1 samples was measured and recorded using a Pawkit water activity meter (Decagon, WA). The calibration was adjusted to $0.760 \mathrm{a}_{\mathrm{w}}$ with an $\mathrm{NaCl}$ standard before measurement.

\subsection{Statistical analyses}

All bacterial plate count experiments were performed in duplicate. Data were subjected to ANOVA (one-way analysis employing SPSS, Version 21, IBM, USA) in order to determine the effect of PME and CNMA concentrations (10 wt\% and $1 \mathrm{wt} \%)$, as compared to the control group, during the storage time for each variable. Duncan's post-hoc test was applied at a significance level of $p<0.05$. The excessive growth ( $>7$ logs) of both types of bacterial cells on Day 35 resulted in ceasing to monitor their growth on Day 28.

\section{Results}

\subsection{Antimicrobial activity of bioactive films against the growth of E.coli}

In the control group trials, the population of artificially inoculated E.coli cells decreased until Day 7, which might be caused by low $\mathrm{a}_{\mathrm{w}}$ value $(0.82)$ of the mant1, and then increased until the last day of storage (Day 28). Also, when bioactive films were used, the population of E.coli cells increased until Day 4. Afterwards, for PCL-PME films, a decrease was continually recorded during the cold storage period. Decreases were also observed with the PCL-CNMA films on Days 7 and 14, though the counts on those days were higher than those on Day 1. For the PCL-CNMA films, as compared to count on Day 1 , the expected decreases were recorded on Days 21 and 28. The difference between Day 1 and Day 28 was $0.31 \mathrm{CFU} / \mathrm{g}$ when PCL-CNMA films were used. For PCL-PME films, the difference between Day 1 and Day 28 was $0.01 \mathrm{CFU} / \mathrm{g}$. In the case of the control group, the cells experienced an increase of $0.39 \mathrm{CFU} / \mathrm{g}$ on Day 28 as compared to Day 1 . At Day 28, the differences between the trials were significant $(\mathrm{p}<0.05)$, and the PCL-CNMA films were found to be effective than the other trials in terms of reducing E.coli growth. As a result, the bacteriostatic effect of the control group was observed for the first 14 days, while the PCL-PME films provided a bacteriostatic effect from Day 7 to Day 28, and the PCL-CNMA films provided a bacteriostatic effect from Days 21 to 28 (Table 1).

In addition, SEM images clearly show that E.coli cells did not adhere to the surfaces of the PCL-CNMA films (data not shown), whereas the opposite was found with regard to the PCL-PME films (Figure 1). Cells were also spotted on mant1 surfaces (data not shown).

\subsection{Antimicrobial activity of bioactive films against the growth of S.aureus}

The CFU counts of the artificially inoculated cells decreased until Day 14 of the $4{ }^{\circ} \mathrm{C}$ storage period in all trials (Control, PCL-PME, PCL-CNMA). There were no significant differences $(p<0.05)$ between the bioactive films, while the differences between the control group and the bioactive films were statistically different on Day $14(\mathrm{p}<0.05)$. In the control group, the cells increased to $5.78 \mathrm{CFU} / \mathrm{g}$ on Day 28, which represents a $0.95 \mathrm{CFU} / \mathrm{g}$ difference from Day 1. Also, the PCL-PME group's cells continued to decrease in number up until Day 21 and then increased on Day 28, representing a $0.31 \mathrm{CFU} / \mathrm{g}$ difference as compared to Day 1. The PCL-CNMA group's cells also continued

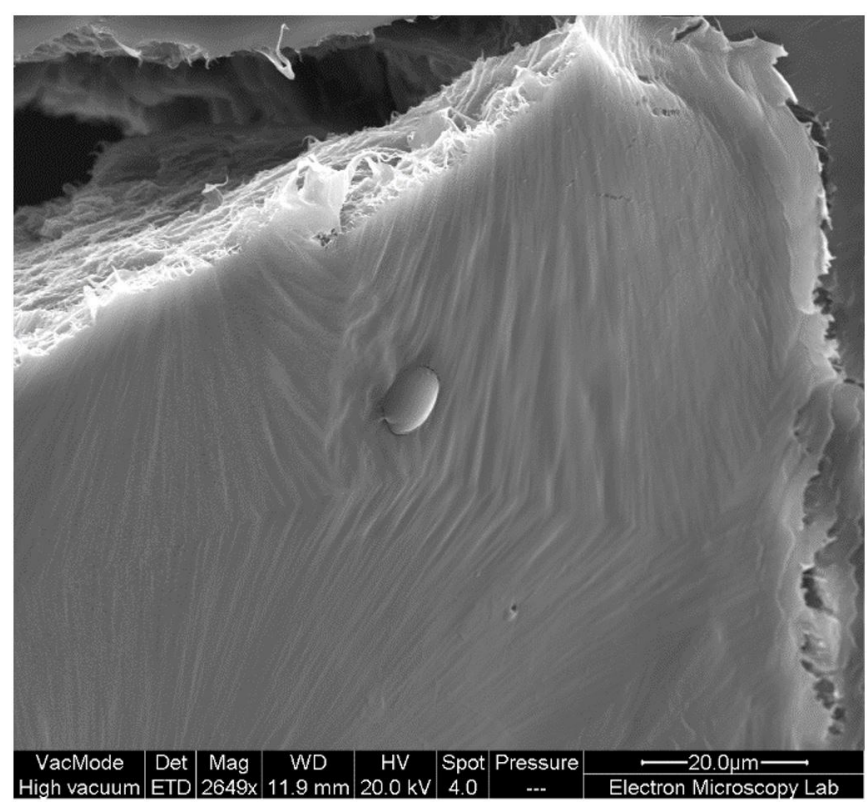

Figure 1. PCL-PME film inoculated with E.coli.

Table 1. Effect of bioactive films on the growth of E. coli.

\begin{tabular}{|c|c|c|c|}
\hline Storage at $4{ }^{\circ} \mathrm{C}^{A}$ (days) & Control $\left(\log _{10} \mathrm{CFU} / \mathrm{g}\right)$ & PCL-PME $\left(\log _{10} \mathrm{CFU} / \mathrm{g}\right)$ & PCL-CNMA $\left(\log _{10} \mathrm{CFU} / \mathrm{g}\right)$ \\
\hline 1 & $5.23 \pm 0.01^{\mathrm{a} B}$ & $5.13 \pm 0.01^{\mathrm{b}}$ & $5.03 \pm 0.01^{c}$ \\
\hline 4 & $5.09 \pm 0.005^{\mathrm{d}}$ & $5.38 \pm 0.02^{\mathrm{e}}$ & $5.40 \pm 0.06^{\mathrm{e}}$ \\
\hline 7 & $4.74 \pm 0.01^{\mathrm{f}}$ & $4.88 \pm 0.03^{g}$ & $5.20 \pm 0.01^{\mathrm{h}}$ \\
\hline 14 & $4.85 \pm 0.01^{\mathrm{i}}$ & $4.82 \pm 0.15^{j}$ & $5.12 \pm 0.01^{j}$ \\
\hline 21 & $5.58 \pm 0.02^{\mathrm{k}}$ & $4.28 \pm 0.02^{1}$ & $4.77 \pm 0.01^{\mathrm{m}}$ \\
\hline 28 & $5.62 \pm 0.03^{n}$ & $5.14 \pm 0.04^{\circ}$ & $4.72 \pm 0.02^{\mathrm{p}}$ \\
\hline
\end{tabular}

${ }^{A}$ (Data in the same row bearing different superscript letters are significantly different $\left.(\mathrm{p}<0.05)\right) ;{ }^{B}$ (Expressed as mean \pm standard deviation). 
to decrease in number up until Day 21 and then increased on Day 28, representing a $0.22 \mathrm{CFU} / \mathrm{g}$ difference as compared to Day 1. On Day 28, the difference between the bioactive films was $0.07 \mathrm{CFU} / \mathrm{g}$, which was a significantly different $(\mathrm{p}<0.05)$.

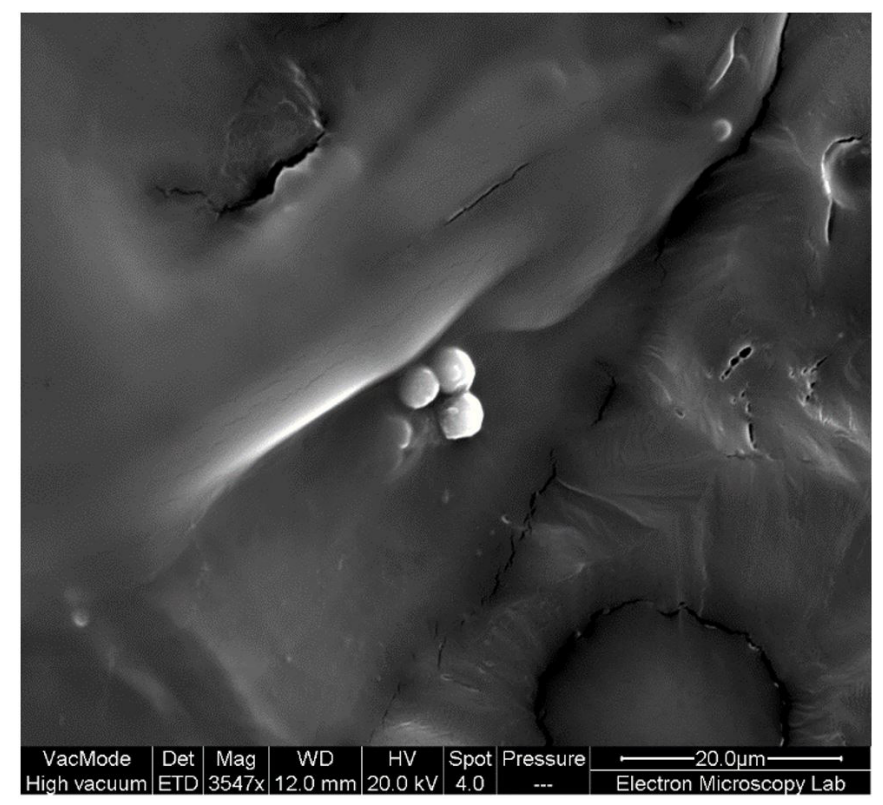

Figure 2. PCL-PME film inoculated with S.aureus.
Therefore, the control group packaging exhibited a continued bacteriostatic effect against $S$. aureus for 14 days at $4{ }^{\circ} \mathrm{C}$, while both of the PCL-PME and PCL-CNMA films suppressed the growth of S.aureus cells for 21 days at $4{ }^{\circ} \mathrm{C}$. On day 21 , the difference between the bioactive films was $0.08 \mathrm{CFU} / \mathrm{g}$, and this difference was significantly different $(\mathrm{p}<0.05)$. As a result, PCL-CNMA films were found to be more effective than the other trials in terms of decreasing the growth of S.aureus cells (Table 2).

Moreover, SEM images clearly show that the S.aureus cells did not adhere to the surfaces of the PCL-CNMA films (data not shown), whereas the opposite was found with regard to PCL-PME films (Figure 2). In addition, the cells were spotted on mantı surfaces (data not shown).

\subsection{Characterisation of the PCL films via ATR-FTIR analysis}

FTIR measurements were provided to observe the bands of the materials that were used in film preparation. The PME absorption band at around $2943 \mathrm{~cm}^{-1}$ is associated with $\mathrm{C}-\mathrm{H}$ stretching (Figure $3 \mathrm{~A}$ ). The spectrum of PCL is characterised by a band at around $1728 \mathrm{~cm}^{-1}$, which is related to carbonyl stretching (Figure $3 \mathrm{C}$ ). The presence of antimicrobial compounds was monitored at $1677 \mathrm{~cm}^{-1}$ for CNMA (Figure $3 \mathrm{~B}$ ), which is associated with $\mathrm{C}=\mathrm{O}$ stretching, while $\mathrm{PME}$ was monitored at 1643,1255 , and $918 \mathrm{~cm}^{-1}$, (Figure 4), which are associated with $\mathrm{C}=\mathrm{O}$ stretching, $\mathrm{C}-\mathrm{O}$ acid stretching, and $\mathrm{O}-\mathrm{H}$ deformation in

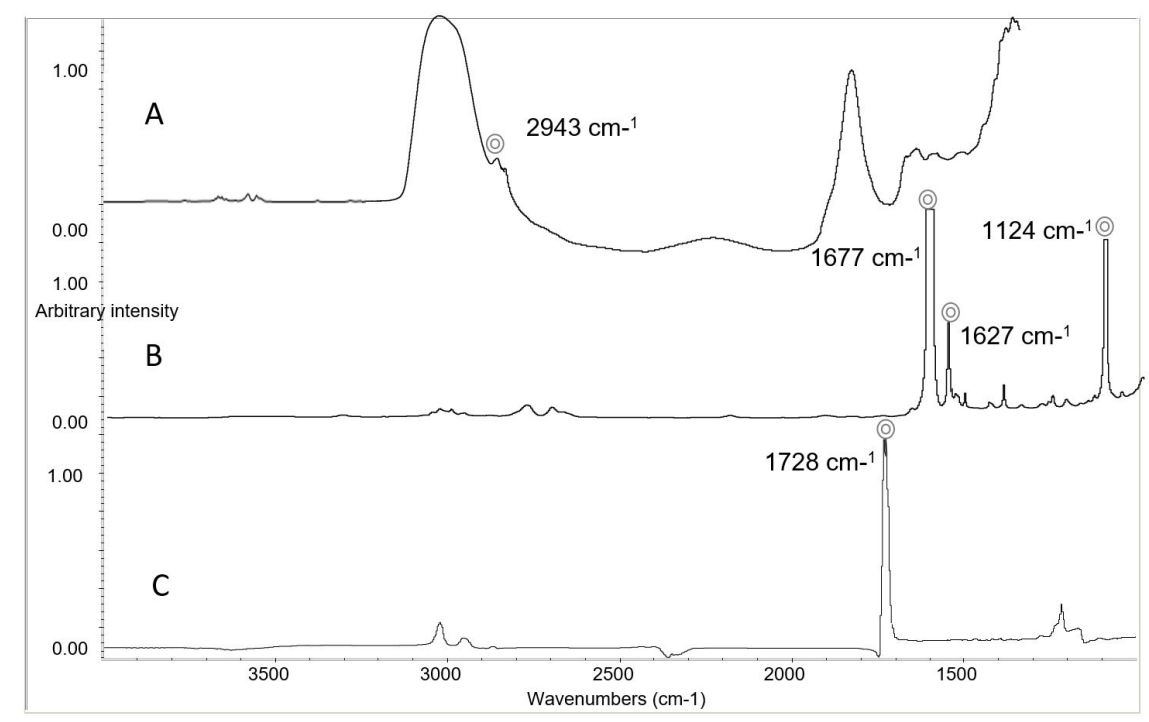

Figure 3. FTIR spectra of PME (A), CNMA (B), and PCL (C).

Table 2. Effect of bioactive films on the growth of S. aureus.

\begin{tabular}{|c|c|c|c|}
\hline Storage at $4{ }^{\circ} \mathrm{C}^{A}$ (days) & Control $\left(\log _{10} \mathrm{CFU} / \mathrm{g}\right)$ & PCL-PME $\left(\log _{10} \mathrm{CFU} / \mathrm{g}\right)$ & PCL-CNMA $\left(\log _{10} \mathrm{CFU} / \mathrm{g}\right)$ \\
\hline 1 & $4.83 \pm 0.01^{\mathrm{a} B}$ & $4.73 \pm 0.01^{\mathrm{b}}$ & $4.79 \pm 0.01^{\mathrm{b}}$ \\
\hline 4 & $4.51 \pm 0.01^{\mathrm{c}}$ & $4.65 \pm 0.01^{\mathrm{d}}$ & $4.75 \pm 0.01^{\mathrm{e}}$ \\
\hline 7 & $4.06 \pm 0.01^{\mathrm{f}}$ & $4.49 \pm 0.01^{\mathrm{g}}$ & $4.3 \pm 0.01^{\mathrm{h}}$ \\
\hline 14 & $3.88 \pm 0.01^{\mathrm{i}}$ & $4.29 \pm 0.01^{\mathrm{j}}$ & $4.29 \pm 0.01^{j}$ \\
\hline 21 & $5.20 \pm 0.01^{\mathrm{k}}$ & $4.18 \pm 0.01^{1}$ & $4.26 \pm 0.01^{\mathrm{m}}$ \\
\hline 28 & $5.78 \pm 0.01^{\circ}$ & $5.04 \pm 0.01^{\mathrm{p}}$ & $4.97 \pm 0.01^{\mathrm{r}}$ \\
\hline
\end{tabular}

${ }^{A}$ (Data in the same row bearing different superscript letters are significantly different $\left.(\mathrm{p}<0.05)\right) ;{ }^{B}$ (Expressed as mean \pm standard deviation). 
acids, respectively. However, the peaks of those antimicrobial compounds disappeared with the addition of CMC, which has characteristic spectra at $2923,1617,1365$, and $1161 \mathrm{~cm}^{-1}$ (Figure 5), which are related to $\mathrm{CH}$ stretching vibration, the carboxyl $\mathrm{C}=\mathrm{O}$ group, the $-\mathrm{CH}$ and $-\mathrm{OH}$ coupled band, $-\mathrm{CO}$ and $-\mathrm{CC}$ stretching, and $-\mathrm{COH}$ and $-\mathrm{CCH}$ bending, respectively.

\section{Discussion}

The antimicrobial activities of PCL-PME and PCL-CNMA films were studied previously (Uzunlu \& Niranjan, 2017). The correspondent compound for pomegranate was explored in that fruit as well. The GC-MS results revealed both flavonoids and non-flavonoids (caffeic and ferulic acids) and palmitic and stearic acids in freeze-dried pomegranate aril samples. The interesting finding of that study is that both of those compounds have antimicrobial activity against E.coli and S.aureus and that methanolic extract of polycaprolactone films (PCL-PME), as are used in the current study, showed higher antimicrobial activity than films prepared with freeze-dried pomegranate arils. Moreover, this antimicrobial activity is thought be more effective in the liquid phase than in the gaseous phase. The bio-active films were directly in contact with the inoculated bacteria in $9 \mathrm{~mm}$ petri plates, and the $3.5 \mathrm{~L}$ of free volume in the closed desiccator was found to be a large enough volume to allow effective antimicrobial activity in the gaseous phase (Uzunlu \& Niranjan, 2017).

The results of the current study are in accordance with findings suggesting that the free volume $(0.6 \mathrm{~L})$ in the modified-atmosphere package is still too high or that the pomegranate methanolic extract has only a very slight antimicrobial effect in the gaseous phase.

The current study is mainly focused on the diffusion of the gaseous phase in the package atmosphere, and there was no direct contact between the packaging and the cells. As a result, the PCL-PME (10\% wt/wt of polymer) films provided antimicrobial activity against both of the tested bacteria up until Day 21. In the case of the earlier study (Uzunlu \& Niranjan, 2017), PCL-PME films (5\% and $10 \% \mathrm{wt} / \mathrm{wt}$ of polymer) allowed no growth during storage at $4{ }^{\circ} \mathrm{C}$ for 28 days when the films were directly in contact with the cells in the free volume of the desiccator. An additional confirmation of this judgement was supplied by SEM images, which showed that both of the bacteria could be found on the PCL-PME films (Figure 1 and Figure 2), while no such bacteria were observed on the PCL-CNMA films (data not shown). Therefore, we can say that in accordance with the earlier study,

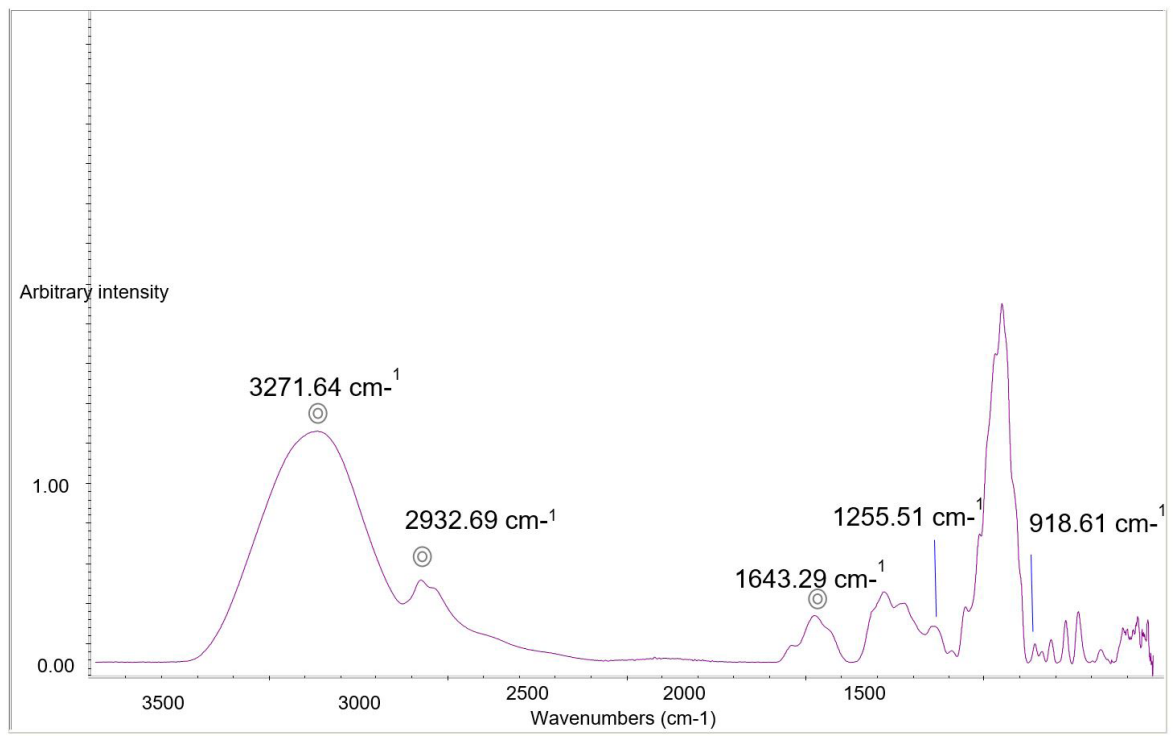

Figure 4. ATR-FTIR spectra of neat PME.

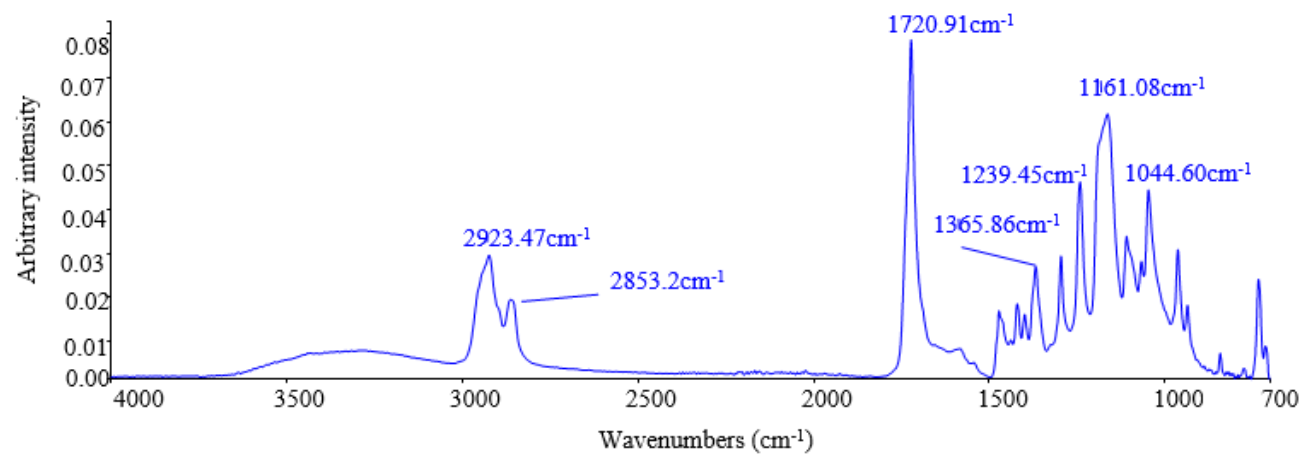

Figure 5. ATR-FTIR spectra of PCL-CMC film. 
cinnamaldehyde films exhibited higher antimicrobial activity than the pomegranate films against E.coli and S.aureus during storage at $4{ }^{\circ} \mathrm{C}$ for 28 days.

Also, PCL-CNMA films have limited antimicrobial activity in the gaseous phase as compared to the liquid phase. An earlier study (Uzunlu \& Niranjan, 2017) investigated the effect of cinnamaldehyde films (5\% and $10 \% \mathrm{wt} / \mathrm{wt}$ of polymer) in direct contact with bacterial cells in the sealed free volume of a desiccator. No growth was observed at $4{ }^{\circ} \mathrm{C}$ for 28 days for either tested bacteria at either of the two concentrations used. In the case of the current results, PCL-CNMA (1\% wt/wt of polymer) films provided antimicrobial activity against S.aureus up until Day 21, and the films resulted in the decline of the E.coli population on Days 21 and 28. This is very much consistent with earlier findings ( $\mathrm{Naz}$ et al., 2007; Negi \& Jayaprakasha, 2003) suggesting that E.coli is more resistant than S.aureus to the studied bioactive compounds. Because the current study employed PCL-CNMA at a $1 \%$ concentration, which is usually avoided due to the negative odour it creates in the package, it is thought that regarding the films' antimicrobial activity, direct contact with the cells during the liquid phase takes precedence over the gaseous phase for the currently studied bioactive compounds of both pomegranate and cinnamon.

Hence, Martínez-Abad et al. (2013) reported that the lipophilic molecules of bioactive compounds forming micelles in the liquid phase, so the attachment of the cells to the bioactive compounds is suppressed, whereas gaseous phase allows free attachment. This could be valid for cinnamaldehyde, which is an essential oil, while pomegranate has little or no lipid content.

This finding should be considered when an active film is intended for food packaging. To minimize current negative consumer perception regarding the direct use of antimicrobials in processed foods, active packaging is key. Therefore, we aimed to test the effects of antimicrobial activity during the vapour phase.

Our findings are in accordance with those of earlier studies on both antimicrobial compounds. Mekkerdchoo et al. (2009) showed an antimicrobial effect on the part of pectin film containing liposome-encapsulated pomegranate, clove oil, and garlic extracts. They reported that the antimicrobial effect was weak when PME was used against the tested microorganisms, including E. coli. Makwana et al. (2014) showed a significant antimicrobial effect against $E$. coli on the part of polylactic acid films cast with CNMA. They reported $2.01 \mathrm{log}$ unit reductions from 7 logs over an incubation period of 48 h. Goñi et al. (2009) showed that the essential oil of cinnamon displayed a larger inhibition zone for $E$. coli than $S$. aureus. Moreover, researchers stated that when cinnamon was combined with essential oil of clove, S. aureus had a larger inhibition zone than E. coli. Sanla-Ead et al. (2012) reported a $20.02 \%$ logarithmic unit reduction when using CNMA-incorporated cellulose-based films against E. coli after 1 day of incubation at $37^{\circ} \mathrm{C}$. Similarly, Takala et al. (2013) reported an antibacterial effect on E. coli on the part of essential oils incorporated in PCL/alginate films.

Mekkerdchoo et al. (2009) showed antimicrobial effects against food spoilage microorganisms, such as selected strains of Pseudomonas, E. coli, Salmonella, and Lactobacillus, on the part of pectin films containing liposome-encapsulated pomegranate, clove oil, and garlic extracts. Sanla-Ead et al. (2012) reported a 1.17 log reduction when using CNMA-incorporated cellulose-based films against $S$. aureus as compared to the control after 1 day of incubation at $37^{\circ} \mathrm{C}$. Additionally, Bowles et al. (1995) reported the inhibition of $S$. aureus's growth by CNMA. Cinnamaldehyde is a principal component of the essential oil of cinnamon, representing $60-75 \%$ of the total oil. Considering its Food and Drug Administration registration as a flavouring agent to be added to food and polymer surfaces for antimicrobial food packaging, it is of interest to food safety researchers (Makwana et al., 2014).

Regarding the ATR-FTIR analysis, the findings are in accordance with those of Martínez-Abad et al. (2013) for CNMA, Martínez-Abad et al. (2013) and Boumail et al. (2013) for PCL, and Vardin et al. (2008) for PME. Moreover, Boumail et al. (2013) showed that the percentage of infrared peaks for antimicrobials (a mixture of liquid smoke and organic acids) progressively decreased over time, which suggests a slow diffusion of volatiles from the films to the packaging headspace. Similarly, in an earlier study, Uzunlu \& Niranjan (2017) showed that a casting period of PCL film with either CNMA (10\% w/w of polymer) or PME (5\% w/w of polymer) resulted in a $20 \%$ wt reduction of the bioactive compounds that were present within the initial film solution. The release of the bioactive compounds from the films was high initially but then stabilised over time. The release rate was higher in PCL-PME films than PCL-CNMA films. It is estimated that $18 \% \mathrm{wt}$ of CNMA (5\% w/w of polymer) and $3 \%$ wt of PME (10\% w/w of polymer) remained after $48 \mathrm{~h}$ of casting (Uzunlu \& Niranjan, 2017). This may be the reason the antimicrobial films showed only a small antimicrobial effect during the early period of the mantı package storage in the current study.

Film thickness, which affects the release rate of essential oils from the films, was measured at $276 \mu \mathrm{m}$. Although it was attempted to decrease the thickness of the film, this increased film breakability (data not shown). Regarding microbial growth, the $\mathrm{a}_{\mathrm{w}}$ of the mant 1 samples was found to be 0.82 . However, it is preferable to reduce this value to below 0.80 to prevent microbial growth. The current study was concerned with antimicrobial effect of films; therefore, nitrogen was used as an inert gas. However, nitrogen-based packaging has an indirect effect on the growth of aerobic microorganisms. It also likely retarded the growth of bacteria in the modified atmosphere package used in the current study. For instance, Singh et al. (2011) have documented that the initial value of the total plate count of pizza samples (6.65 log CFU/g) was below 7 logs CFU/g over 20 days of refrigerated storage when packed with $100 \% \mathrm{~N}_{2}, 100 \% \mathrm{CO}_{2}$, and $50 \% \mathrm{CO}_{2}+50 \% \mathrm{~N}_{2}$. Also, air-packed samples reached an unsatisfactory result ( $>7$ logs) within 10 days.

In addition, Takala et al. (2013) found that the mechanism via which the volatiles are released from the films during cold storage may be altered by relative humidity. Furthermore, they state that the respiration of plant foods resulted in the hydration of active films and thus led to a decrease in antimicrobial effect. 


\section{Conclusion}

In conclusion, cinnamaldehyde and pomegranate methanolic extract films controlled microbial growth in a modified-atmosphere package during cold storage.

\section{Acknowledgements}

The Council of Higher Education of Turkey is acknowledged for its financial support under the research grant of Sinan Uzunlu. Professor Keshavan Niranjan and Dr Afroditi Chatzifragkou at the University of Reading is appreciated for providing facilities and helpful assistance.

\section{References}

Boumail, A., Salmieri, S., Klimas, E., Tawema, P. O., Bouchard, J., \& Lacroix, M. (2013). Characterization of trilayer antimicrobial diffusion films (ADFs) based on methylcellulose-polycaprolactone composites. Journal of Agricultural and Food Chemistry, 61(4), 811821. http://dx.doi.org/10.1021/jf304439s. PMid:23286547.

Bowles, B. L., Sackitey, S. K., \& Williams, A. C. (1995). Inhibitory effects of flavour compounds on Staphylococcus aureus WRRC B124. Journal of Food Safety, 15(4), 337-347. http://dx.doi. org/10.1111/j.1745-4565.1995.tb00144.x.

Duman, A. D., Ozgen, M., Dayisoylu, K. S., Erbil, N., \& Durgac, C. (2009). Antimicrobial activity of six pomegranate (Punica granatum L.) varieties and their relation to some of their pomological and phytonutrient characteristics. Molecules, 14(5), 1808-1817. http:// dx.doi.org/10.3390/molecules14051808. PMid:19471201.

Goñi, P., López, P., Sánchez, C., Gómez-Lus, R., Becerril, R., \& Nerín, C. (2009). Antimicrobial activity in the vapour phase of a combination of cinnamon and clove essential oils. Food Chemistry, 116(4), 982989. http://dx.doi.org/10.1016/j.foodchem.2009.03.058.

Hafsa, J., Smach, M., Ben Khedher, M. R., Charfeddine, B., Limem, K., Majdoub, H., \& Rouatbi, S. (2016). Physical, antioxidant and antimicrobial properties of chitosan films containing Eucalyptus globulus essential oil. Lebensmittel-Wissenschaft + Technologie, 68, 356-364. http://dx.doi.org/10.1016/j.lwt.2015.12.050.

Makwana, S., Choudhary, R., Dogra, N., Kohli, P., \& Haddock, J. (2014). Nanoencapsulation and immobilization of cinnamaldehyde for developing antimicrobial food packaging material. LebensmittelWissenschaft + Technologie, 57(2), 470-476. http://dx.doi.org/10.1016/j. lwt.2014.01.043.

Marder, E. P., Cieslak, P. R., Cronquist, A. B., Dunn, J., Lathrop, S., Rabatsky-Ehr, T., Ryan, P., Smith, K., Tobin-D’Angelo, M., Vugia, D. J., Zansky, S., Holt, K. G., Wolpert, B. J., Lynch, M., Tauxe, R., \& Geissler, A. L. (2017). Incidence and Trends of Infections with Pathogens Transmitted Commonly Through Food and the Effect of Increasing Use of Culture-Independent Diagnostic Tests on Surveillance - Foodborne Diseases Active Surveillance Network, 10 U.S. Sites, 2013-2016. Centers for Disease Control and Prevention Report Morbidity and Mortality Weekly Report, 66(15), 397-403. http://dx.doi.org/10.15585/mmwr.mm6615a1. PMid:28426643.

Martínez-Abad, A., Sánchez, G., Fuster, V., Lagaron, J. M., \& Ocio, M. J. (2013). Antibacterial performance of solvent cast polycaprolactone
(PCL) films containing essential oils. Food Control, 34(1), 214-220. http://dx.doi.org/10.1016/j.foodcont.2013.04.025.

Mekkerdchoo, O., Patipasena, P., \& Borompichaichartkul, C. (2009). Liposome encapsulation of antimicrobial extracts in pectin film for inhibition of food spoilage microorganisms. Asian Journal of Food and Agro-Industry, 2(4), 817-838.

Nanasombat, S., \& Wimuttigosol, P. (2011). Antimicrobial and antioxidant activity of spice essential oils. Food Science and Biotechnology, 20(1), 45-53. http://dx.doi.org/10.1007/s10068-011-0007-8.

Naz, S., Siddiqi, R., Ahmad, S., Rasool, S. A., \& Sayeed, S. A. (2007). Antibacterial activity directed isolation of compounds from Punica granatum. Journal of Food Science, 72(9), M341-M345. http://dx.doi. org/10.1111/j.1750-3841.2007.00533.x. PMid:18034726.

Negi, P. S., \& Jayaprakasha, G. K. (2003). Antioxidant and antibacterial activities of Punica granatum peel extracts. Journal of Food Science, 68(4), 1473-1477. http://dx.doi.org/10.1111/j.1365-2621.2003. tb09669.x.

Sanla-Ead, N., Jangchud, A., Chonhenchob, V., \& Suppakul, P. (2012). Antimicrobial activity of cinnamaldehyde and eugenol and their activity after incorporation into cellulose-based packaging films. Packaging Technology \& Science, 25(1), 7-17. http://dx.doi.org/10.1002/pts.952.

Singh, P., Wani, A. A., \& Goyal, G. K. (2011). Quality of chilled readyto-bake pizza stored in air and under modified atmospheres: Microbiological and sensory attributes. Food Science and Biotechnology, 20(1), 1-6. http://dx.doi.org/10.1007/s10068-011-0001-1.

Sitti, S. (2011). Vakum ve modifye atmosfer ambalajlamanın Kayseri mantısının bazı kalite nitelikleri üzerine etkisi (Master's thesis). Erciyes University, Kayseri.

Takala, P. N., Vu, K. D., Salmieri, S., Khan, R. A., \& Lacroix, M. (2013). Antibacterial effect of biodegradable active packaging on the growth of Escherichia coli, Salmonella typhimurium and Listeria monocytogenes in fresh broccoli stored at $4^{\circ} \mathrm{C}$. Lebensmittel-Wissenschaft + Technologie, 53(2), 499-506. http://dx.doi.org/10.1016/j.lwt.2013.02.024.

Uzunlu, S., \& Niranjan, K. (2017). Laboratory antimicrobial activity of cinnamaldehyde and pomegranate-based polycaprolactone films. Journal of Applied Polymer Science, 134(39), 1-9. http://dx.doi. org/10.1002/app.45347.

Uzunlu, S., \& Var, I. (2016). Effect of Modified Atmosphere Packaging on the Refrigerated Storage of Mant1. Turkish Journal of Agriculture Food Science and Technology, 4(1), 36-40. http://dx.doi.org/10.24925/ turjaf.v4i1.36-40.535.

Vardin, H., Tay, A., Ozen, B., \& Mauer, L. (2008). Authentication of pomegranate juice concentrate using FTIR spectroscopy and chemometrics. Food Chemistry, 108(2), 742-748. http://dx.doi. org/10.1016/j.foodchem.2007.11.027. PMid:26059156.

Wen, P., Zhu, D. H., Wu, H., Zong, M. H., Jing, Y. R., \& Han, S. Y. (2016). Encapsulation of cinnamon essential oil in electrospun nanofibrous film for active food packaging. Food Control, 59, 366-376. http:// dx.doi.org/10.1016/j.foodcont.2015.06.005.

Yam, K. L., \& Zhu, X. (2012). Emerging food packaging technologies principles and practice. In K. Yam, \& D. S. Lee (Eds.), Controlled release food and beverage packaging. (pp. 13-26). Philadelphia: Publ. Woodhead Publishing Limited.

Yücetepe, A. (2011). Modifiye atmosferde ambalajlamanın etli mantının kalitesi üzerine etkileri (Master's thesis). Istanbul Technical University, Istanbul. 